\title{
Response of Egyptian Clover to Cutoff Irrigation Technique on Clay Soils at North Nile Delta
}

\author{
Kassab, M.M.; R. Kh. Darwesh and M.A.M. Ibrahim ${ }^{1}$
}

\begin{abstract}
A field trial was carried out at Sakha Agricultural Research Station, Kafr El-Sheikh Governorate during the two successive winter seasons 2010/2011 and 2011/2012. The aim of the work was to assess the effect of irrigation lengths on barseem yield and its water parameters. Five irrigation lengths were examined; $\mathbf{1 0 0 \%}$ of strip length (S.L) as control (Trt. A), $95 \%$ (Trt. B), 90\% S.L(Trt. C), $85 \%$ S.L(Trt. D) and $80 \%$ S.L (Trt. E). Average of seasonal water applied were, in adescending order as follow: $\mathrm{A}(2615.0)>\mathrm{B}(2507.7)>\mathrm{C}(2409.0)>\mathrm{D}(2330.5)>$ $E(2215.1) \mathrm{m}^{3}$ fed $^{-1}$. Mean values of water saving in the two growing seasons comparing with the control 107.4, 206.0, 284.5 and $400.0 \mathrm{~m}^{3}$ fed $^{-1}$ or $4.1,7.9,10.9$, and $15.3 \%$ for the cut off treatments $B, C, D$ and $E$ respectively. The highest average of yield per unit of applied water (W Ut E) and consumed water (W $U$ E) averaging 16.58 and $24.80 \mathrm{~kg} \mathrm{~m}^{-3}$ for each, respectively were obtained under $90 \%$ S.L (Trt C).
\end{abstract}

\section{INTRODUCTION}

The water shortage problem in Egypt is continuously increasing and prospected to reach less than $500 \mathrm{~m}^{3} / \mathrm{yr} /$ capita. In order to cope with the shortage of water, tremendous efforts should be implemented. One of the most effective ways of the irrigation management on the farm is to select the proper irrigation scheduling and crop rotation. Water excessive as well as insufficient irrigation results in decreasing crop yield. Egyptian clover (Trifolium alexandrinum $L$.) is one of the most important forage legume crops in some world countries particularly that has long winter season with cold- moderate temperature. Strip or border irrigation is a common type of surface irrigation, most suitable for berseem irrigation especially in clay soil. Under traditional irrigation practiced by local farmers the wetting front is allowed to reach the tail end of the border. Therefore, a long time is allowed for water to stay in the upper portion of the irrigated strip which results in more water losses by deep percolation. So that cut off technique procedure could be implemented i.e. irrigation front should stop before the end of the cultivated border. Such procedure considered as a direct simple effective way in water saving. As, less water will percolate down to the drainage system at the area. Irrigated parameters of berseem were studied widely in Egypt and worldwide. Kassab and Ibrahim (2007) revealed that cutoff wheat irrigation as an effective technique for improving water management via saving an amount of irrigation water. Also they stated that highest values of crop-water functions i.e. W Ut E $\left(1.61 \mathrm{kgm}^{-3}\right)$ and W Us E $\left(1.73 \mathrm{kgm}^{-3}\right)$ obtained from $90 \%$ of strip length. Mahrous et al (1984) concluded that to obtain high yield of Egyptian clover, available moisture should be maintained between 40 to $60 \%$ depletion of the available soil moisture. Thus, low yield of Egyptian clover is correlated with low level of soil moisture (Badawi, 1970). So, the objective of this study was to identify the most suitable cut off related to berseem irrigation under border watering i.e. when to stop the irrigation front. The specific goals were to determine the amount water saving under this technique and to compute berseem water relations.

\section{MATERIALS AND METHODS}

The current study was conducted at Sakha Agricultural Research Station, Kafr El-Sheikh Governorate during the two winter seasons 2010/2011 and $2011 / 2012$, to study the effect of strip length on berseem crop as well as some water relation. Soil of the experimental field was clayey in texture table (1).

Berseem was sown on October 16, 2010 and october22, 2011 with dry broadcasting method. Dates of cutting $(\mathrm{C})$ were as fallow

$$
\begin{array}{cccc}
\text { - Season 1: } \quad C_{1}=4 / 1 / 2011, & C_{2}= & 18 / 2 / 2011, \\
\quad C_{3}=3 / 4 / 2011, \quad C_{4}=2 / 5 / 2011 & & \\
\text { - Season 2: } \quad C_{1}=7 / 1 / 2012, & C_{2}= & 20 / 2 / 2012, \\
\quad C_{3}=8 / 4 / 2012, \quad C_{4}=10 / 5 / 2012 &
\end{array}
$$

All the used agronomic practices in the study area were followed except the length of irrigation run treatments which were as follows:
A- $100 \%$ strip length (control)
B- Cut off at $95 \%$ of strip length
C- Cut off at $90 \%$ of strip length
D- Cut off at $85 \%$ of strip length
E- Cut off at $80 \%$ of strip length

Length of each cultivated strip was $70 \mathrm{~m}$ and width $3 \mathrm{~m}$, irrigation was stopped when water front reached 70.0 (control) treatment, 66.3, 63.0, 59.5 and $56.0 \mathrm{~m}$ for A,B,C,D and E, respectively. The experimental design was in a complete randomized block design with four replicates. Each strip unit included 6 ridges, $60 \mathrm{~cm}$ apart redundant, the area of strip was $210 \mathrm{~m}^{2}$ i.e. $1 / 20 \mathrm{fed}$.

\footnotetext{
${ }^{1}$ Soils, Water and Environment Res. Inst., Agric., Res. Cent. Egypt
} Received July1 17, 2012, Accepted September 30, 2012 
Table 1. Some physical and chemical characteristics of the studied soils before cultivating the crop

\begin{tabular}{|c|c|c|c|c|c|c|c|c|c|c|c|}
\hline \multirow{3}{*}{$\begin{array}{l}\text { Soil depth } \\
\quad \text { (cm) }\end{array}$} & \multicolumn{11}{|c|}{ Physical characteristics } \\
\hline & \multicolumn{3}{|c|}{ Particle size distribution $\%$} & \multirow{2}{*}{\multicolumn{2}{|c|}{ Texture class }} & \multirow{2}{*}{$\begin{array}{c}\text { Bulk } \\
\text { density } \\
\mathrm{Mg} / \mathrm{m}^{3}\end{array}$} & \multirow{2}{*}{$\begin{array}{c}\text { Total } \\
\text { porosity } \\
\%\end{array}$} & \multirow{2}{*}{\multicolumn{2}{|c|}{$\begin{array}{c}\text { Field } \\
\text { capacity } \\
\% \\
\end{array}$}} & \multirow{2}{*}{$\begin{array}{c}\text { PWP } \\
\%\end{array}$} & \multirow{2}{*}{$\begin{array}{c}\text { A.W } \\
\%\end{array}$} \\
\hline & Sand & Silt & Clay & & & & & & & & \\
\hline $0-15$ & 12.3 & 33.3 & 54.4 & & & 1.26 & 52.45 & 47 & & 25.69 & 21.81 \\
\hline $15-30$ & 20.2 & 34.2 & 45.6 & & ay & 1.30 & 50.94 & 39 & & 21.66 & 18.21 \\
\hline $30-45$ & 20.4 & 41.4 & 38.2 & Clas & loam & 1.29 & 51.32 & 38 & & 20.86 & 17.54 \\
\hline $45-60$ & 21.1 & 41.5 & 37.4 & Cla & loam & 1.38 & 47.92 & 36 & & 19.78 & 16.61 \\
\hline \multirow{3}{*}{$\begin{array}{l}\text { Depth } \\
\text { cm }\end{array}$} & \multicolumn{10}{|c|}{$\begin{array}{l}\text { Chemical characteristics } \\
\end{array}$} & \multirow{3}{*}{$\mathbf{p H}$} \\
\hline & \multirow{2}{*}{ ESP } & \multirow{2}{*}{$\begin{array}{c}\text { E.C } \\
\text { dS/m }\end{array}$} & \multicolumn{4}{|c|}{ Soluble cations, mmole/l } & \multicolumn{4}{|c|}{ Soluble anions mmole/l } & \\
\hline & & & $\mathrm{Ca}^{++}$ & $\mathrm{Mg}^{++}$ & $\mathrm{Na}^{+}$ & $\mathbf{K}^{+}$ & $\mathrm{CO}_{3}$ & $\mathrm{HCO}_{3}$ & $\mathrm{Cl}^{-}$ & $\mathrm{SO4}$ & \\
\hline $\mathrm{p} 0-15$ & 6.61 & 4.8 & 23.90 & 16.9 & 25.6 & 0.41 & 0.00 & 3.60 & 15.0 & 48.21 & 8.17 \\
\hline $15-30$ & 8.44 & 5.2 & 15.90 & 19.8 & 30.0 & 0.42 & 0.00 & 3.50 & 25.0 & 37.62 & 8.05 \\
\hline $30-45$ & 10.19 & 5.2 & 21.20 & 9.8 & 43.0 & 0.47 & 0.00 & 3.10 & 20.0 & 51.37 & 8.30 \\
\hline $45-60$ & 8.41 & 5.1 & 20.30 & 15.4 & 32.8 & 0.43 & 0.00 & 3.30 & 20.0 & 45.63 & 8.17 \\
\hline
\end{tabular}

PWP $=$ Permanent wilting point, $\mathrm{AW}=$ Available water

Execution and data collected:

\section{1- Irrigation control:-}

Irrigation water was controlled and measured by a constructed rectangular weir in the experimental field with a discharge rate of $0.01654 \mathrm{~m}^{3} / \mathrm{sec}$ at $10 \mathrm{~cm}$ as effective head over the crest. Distribution of irrigation water was maintained by spills inserted beneath the strip bank.

\section{2- Advance and recession curves:}

Along each strip, different stations $10 \mathrm{~m}$ apart were put all the way till the end of the proposed irrigation run. Time of advanced water front at each station and at the end was recorded from the beginning of watering event. The corresponding elapsed time, for the disappear of water at each station was also recorded. The vertical distance between the two curves of advance and recession indicated or expressed as the opportunity time of irrigation water at each station.

\section{2- Water-consumptive use:}

Soil moisture percentage was determined (on weight basis) before and after each irrigation as well as at harvest to compute the actual consumed water of the growing plants, as stated by Hansen et al. (1979).

$\mathrm{CU}=$ S.M.D. $=\sum_{\mathrm{i}=1}^{\mathrm{i}=4} \frac{\phi_{2}-\phi_{1}}{100} \times \mathrm{D}_{\mathrm{bi}} \times \mathrm{D}_{\mathrm{i}}$

\section{Where:}

$\mathrm{CU}=$ Water consumptive use $(\mathrm{cm})$ in the effective root zone of $60 \mathrm{~cm}$ depth $=$ S.M.D. (soil moisture depletion).

I = Number of soil layer (1-4)

$\mathrm{D}_{\mathrm{i}}=$ Soil layer thickness $(15 \mathrm{~cm})$,
$D_{b i}=$ Bulk density $\left(\mathrm{Mg} / \mathrm{m}^{3}\right)$ of the concerned layer.

$\phi_{1}=$ Soil moisture percentage before irrigation and

$\phi_{2}=$ Soil moisture percentage, 48 hours after irrigation.

3- Crop yield:

The obtained data of crop yield for each cut, the seasonal yield was subjected to states analyses according to Snedecor and Cochran (1967)

\section{4- Crop-Water efficiency:}

Crop water efficiency was calculated according to Doorenbos and Pruitt (1975), as follows:

$\mathrm{WUtE}=\frac{\mathrm{Y}}{\mathrm{Wa}}$

$\mathrm{WusE}=\frac{\mathrm{Y}}{\mathrm{CU}}$

Where:

WUtE $=$ Water utilization efficiency $\left(\mathrm{kg} / \mathrm{m}^{3}\right)$.

WUsE $=$ Water use efficiency $\left(\mathrm{kg} / \mathrm{m}^{3}\right)$.

$\mathrm{Y} \quad=$ Seasonal yield $\mathrm{kg} / \mathrm{fed}$.

$\mathrm{Wa}=$ Seasonal water applied and

$\mathrm{CU}=$ Seasonal crop-water consumed.

\section{5- Consumptive use efficiency (Ecu):}

Values of consumptive use efficiency (Ecu) was calculated by Doorenbos and Pruitt (1975).

$\mathrm{Ecu}=\frac{\mathrm{ETc}}{\mathrm{Wa}} \times 100$ 
Where:

$\mathrm{Ecu}=$ Consumptive use efficiency

$\mathrm{ETc}=$ Total cevapotranspiration $\simeq$ consumptive use

$\mathrm{Wa}=$ Water applied to the field.

\section{RESULTS AND DISCUSSION}

\section{Water parameters:}

\section{a) Seasonal water applied (Wa):}

Water applied to the Egyptian clover (Berseem) consists of two components, irrigation water (I W) and rainfall (RF) as shown in Table (2). Seasonal rainfall was 172.1 and $122.56 \mathrm{~mm}$ during the two growing seasons of 2010/2011 and 2011/2012 respectively. Mean values of the treatments of applied irrigation water during the course of study of the two seasons showed that the control (Trt.A no cut off. $100 \%$ SL) has the highest $\mathrm{Wa}\left(2615.01 \mathrm{~m}^{3} \mathrm{fed}^{-1}\right)$. This amount of water is the summation of $1996.14 \mathrm{~m}^{3} \mathrm{fed}^{-1}$ as irrigation water and $618.87 \mathrm{~m}^{3}$ as rainfall. Strip length of $80 \%$ (Trt E) received the lowest average of water applied $\left(2215.05 \mathrm{~m}^{3} \mathrm{fed}^{-1}\right)$, which consists of $1596.18 \mathrm{~m}^{3}$ as irrigation water and $618.87 \mathrm{~m}^{3}$ as rainfall. There for, total water applied could be arranged in descending order as; $\mathrm{A}(2615.01)>\mathrm{B}(2507.66)>\mathrm{C}(2409.4)>$ $\mathrm{D}(2330.53)>\mathrm{E}(2215.05) \mathrm{m}^{3} \mathrm{fed}^{-1}$

In comparison with the control (Trt.A no cut off. ) the mean water saving in the two growing seasons were $4.1,7.9,10.9$, and $15.3 \%$ for the cut off treatments B, C, $\mathrm{D}$ and $\mathrm{E}$, respectively.

Meaningfully, 9-10 m was wetted under treatment E of $80 \%$ SL cut off, while it was $3.5 \mathrm{~m}$ for the $95 \% \mathrm{SL}$ cut off (Trt. B). This is the main advantage of using such technique of cut off watering to save same irrigation water.

Therefore, by irrigating $95 \%$ and $90 \%$ from the border length instead of the traditional watering till the end of the strip (Trt. A), the remaining dry area of 3.5 and $7.0 \mathrm{~m}$ could be wetted by the accumulated water of the irrigated area of $95 \%$ and $90 \%$ S.L. i.e. treatments $\mathrm{B}$ and $\mathrm{C}$, respectively. Moreover, saving water with $4.1 \%$ and $7.9 \%$ could be obtained along with less water could be drained.These findings are agreeded with those obtained with Emara and Ibrahim (2004), they found that irrigated beet crop till $90 \%$ from the furrow length almost $9.97 \%$ saving water could be resulted.

The advancement of water front still going on towards the lower end of the border, after stop if irrigation as shown in table (3).

\section{b. Advance, recession curves and opportunity time:}

Figl (A,B,C,D,E) the trend of the advance and recession which are almost parallel for all treatments. The opportunity time, is affected by the cut-off treatments. The opportunity time has the adverse direction with the level of cut-off. Meaningfully, by increasing the length of irrigation run (traditional without cut-off) the highest opportunity time is resulted and vise versa.

So, it is obvious that by irrigating only $90 \%$ from cultivated strip (Trt. C), the corresponding time is less than that of Trt. A and this means less water could be drained underneath the root zone.

\section{Crop consumptive use (ETc):}

Seasonal crop water consumptive use (CU) which referred to crop evapotranspiration (ETc) has the same trend as that of the applied water. Consumptive use is a direct function of the soil moisture. Values of seasonal consumptive use under different rates of berseem crop are presented in Table 2. The overall average values of seasonal consumptive use in the two growing seasons are ; $\mathrm{A}(42.76)>\mathrm{B}(40.33)>\mathrm{C}(38.30)>\mathrm{D}(37.27)>\mathrm{E}$ $(35.00) \mathrm{cm}$. the highest mean vale of $42.76 \mathrm{~cm}$ with $100 \%$ S.L (Trt. A), resulted from irrigation till the end of the cultivated border. This is due to the highest water delivered to treatment $\mathrm{A}$. On the other hand, the lowest value $35.00 \mathrm{~cm}$ resulted from $80 \%$ S.L (Trt. E). in addition from the same Table 2 the mean values of seasonal rate of $\mathrm{CU}$ for the treatments have the same trend. They were 2.14,2.02,1.92,1.86 and $1.75 \mathrm{~mm} /$ day, respectively. The results are in the agrement with that reported by Kassab and Ibrahim 2007 and Azevedo et al 2003

\section{Crop-water efficiencies:}

Crop-water efficiency indicates the productivity of unit water. This it can be evaluated in two terms of water utilization efficiency (WUt.E) which related with water applied and water use efficiency (WUsE) for water consumed. The average values of water utilization efficiency (WUt.E), of the two seasons for treatments A, B, C, D and E were 15.40, 16.08, 17.22, 15.99 and $15.58 \mathrm{~kg} / \mathrm{m}^{3}$, respectively (Table 2). Moreover, treatment C $(90 \%$ S.L) recorded the highest average of W.Ut.E of $16.58 \mathrm{~kg} / \mathrm{m}^{3}$. While the lowest value 15.40 $\mathrm{kg} / \mathrm{m}^{3}$ was obtained from control (100\% S.L.).

Concerning, water use efficiency (W.Us.E), mean values of WUsE for treatments A, B, C, D and E were $22.38,23.77,24.80,24.21$ and $23.65 \mathrm{~kg} / \mathrm{m}^{3}$ (Table 2). The highest $24.80 \mathrm{~kg} / \mathrm{m}^{3}$ was recorded with treatment C $\left(90 \%\right.$ S.L), while the lowest $22.38 \mathrm{~kg} / \mathrm{m}^{3}$ was resulted from control (100\% S.L.). Therefore, one $\mathrm{kg}$ Berseem needs about $42.1 \mathrm{~L}$ of consumed water.

This finding is in a good agreement with those obtained by Abass et al.(1995) found that optimum irrigation efficiency increased under stress conditions than well watering condations. 


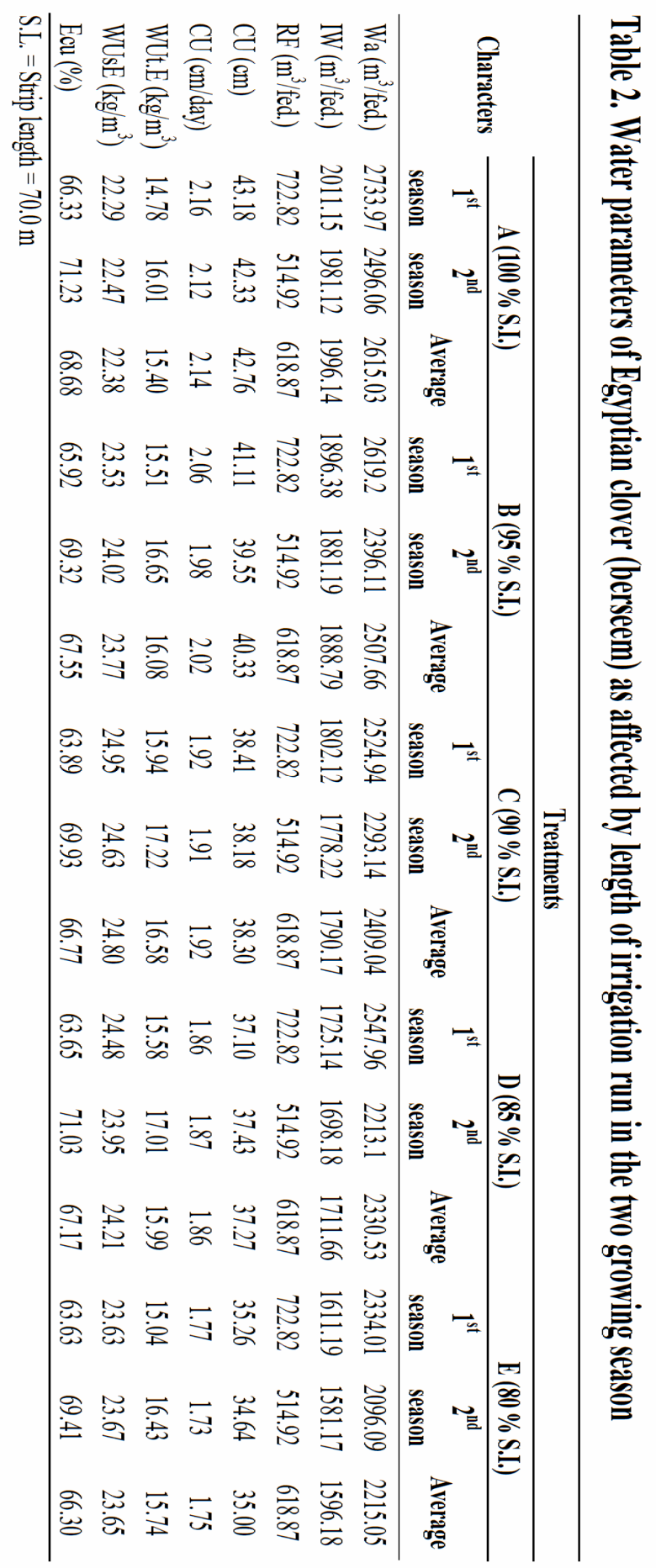




\section{Fresh and dry yield of Egyptian clover}

Length of irrigation run had a significant effect on berseem yield in both seasons as shown in Tables(4,5). Almost the same yield was obtained under treatments $100 \%$ of strip length (S.L) as control (Trt. A), $95 \%$ (Trt. B), $90 \%$ S.L(Trt. C). the mean corresponding values were; $40.19,40.27$ and 39.88 ton / fed. This finding could be attributed to that the un-irrigation area for the cut off treatments $\mathrm{B}$ and $\mathrm{C}$ were irrigated from the accumulative water after the stopping of watering events. This is a remarkable finding that is not necessary to irrigating the berseem crop till the trial end of the cultivated strip. On the other hand, the lowest yield of 34.76 ton / fed. Was recorded for $80 \%$ of SL.Similar results were obtained by Abo-warda (2002),

\section{Consumptive use efficiency (Ecu):}

Consumptive use efficiency (Ecu) is a parameter which indicates the capability of plants to utilize the soil moisture stored in the effective roots zone. Table (2) show that the highest value of Ecu was showed that $68.68 \%$ (100\% S.L., Trt. A.). while the lowest value of of Ecu was $66.36 \%$ (80\% S.L., Trt. E.).

Other treatments have values in between. These results agree with those of Doorenbos et al (1979) who stated that the consumptive use efficiency increased with the increase of consumptive use and with the decrease in water applied.

Table 3. Average of soil distance without irrigation and reach time to stop water front (W.F.) irrigation cut off for different treatments

\begin{tabular}{lccc}
\hline \multicolumn{1}{c}{ Treatments } & Unirrigated distance & W.F. advancement after cut off & Time to stop (W.F) \\
\hline $\mathrm{A}=100 \%$ of S.L. (control) & None & None & None \\
$\mathrm{B}=95 \%$ of SL & $3.5 \mathrm{~m}$ & $=3.5 \mathrm{~m}$ & $12-14 \mathrm{~min}$. \\
$\mathrm{C}=90 \%$ of SL & $7.0 \mathrm{~m}$ & $=7.0 \mathrm{~m}$ & $20-22 \mathrm{~min}$. \\
$\mathrm{D}=85 \%$ of SL & $10.5 \mathrm{~m}$ & $\simeq 10.5 \mathrm{~m}$ & $30-32 \mathrm{~min}$. \\
$\mathrm{E}=80 \%$ of SL & $14.0 \mathrm{~m}$ & $\simeq 10 \mathrm{~m}$ & $30-34 \mathrm{~min}$. \\
\hline
\end{tabular}

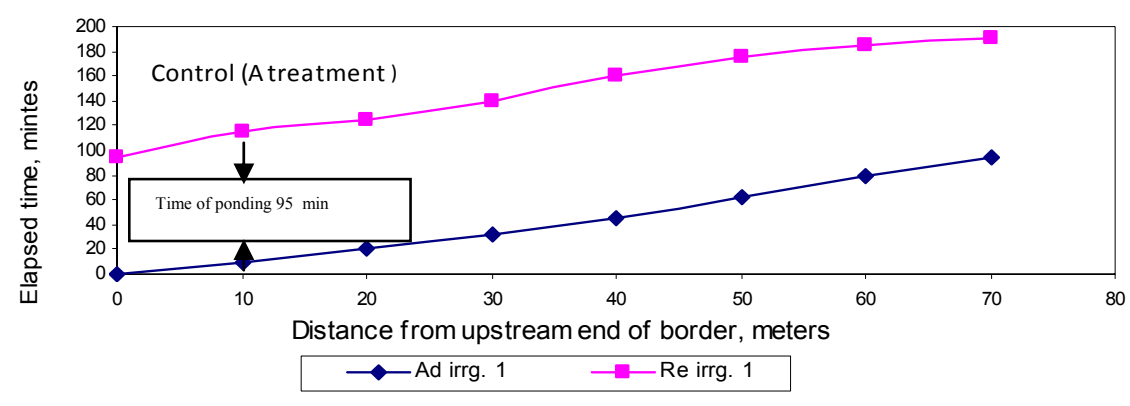



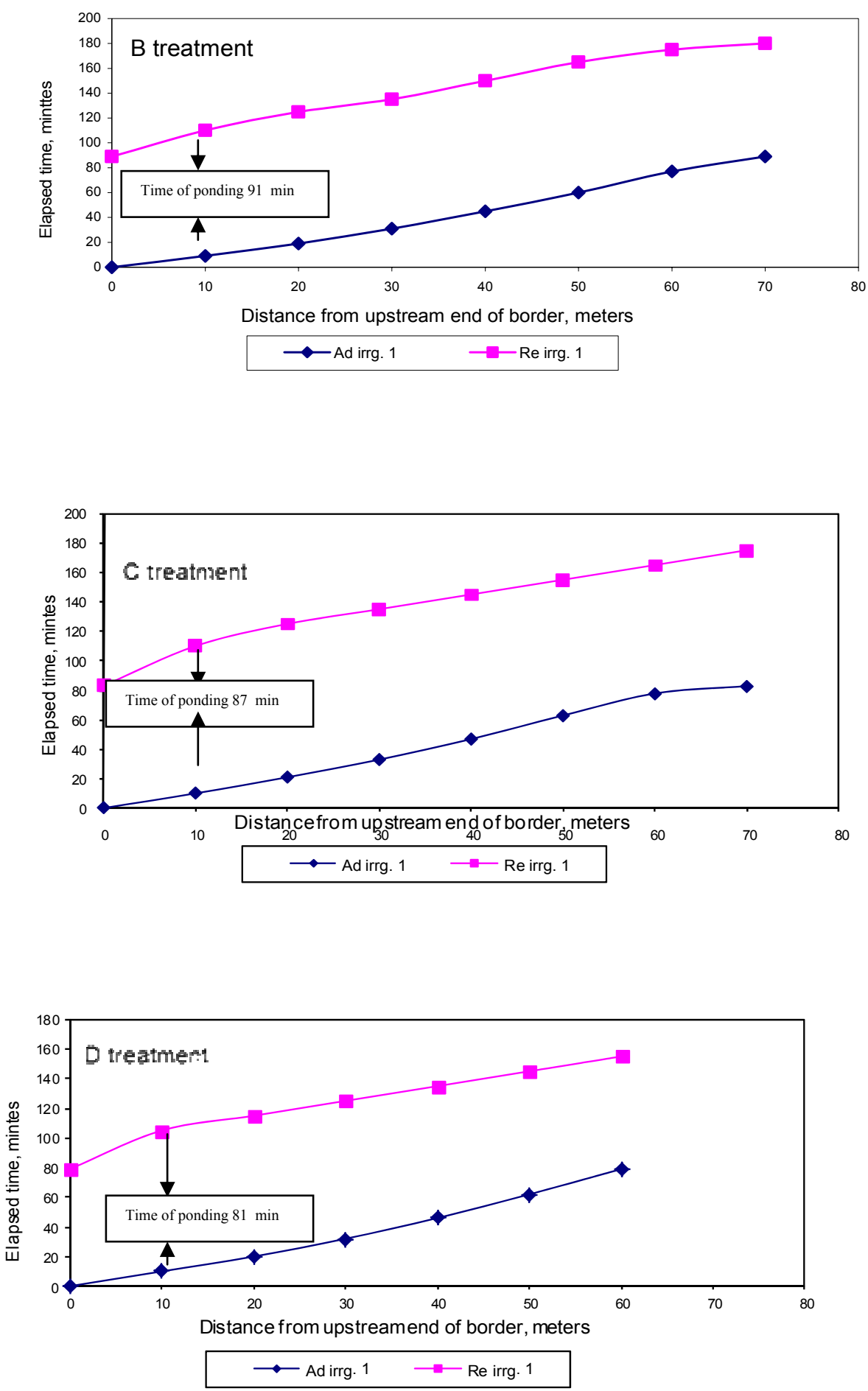


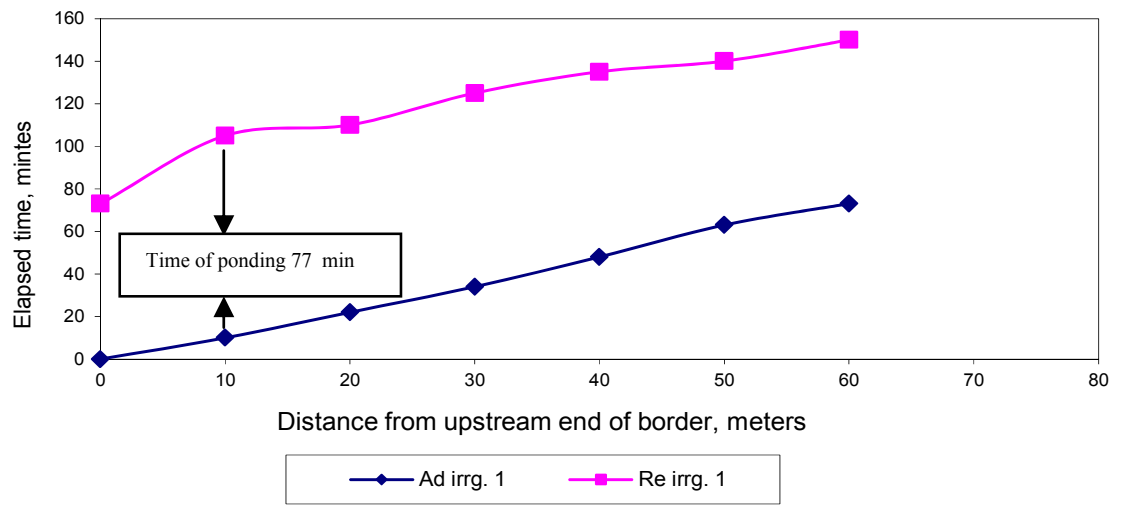

Fig.1. irrigated length and elapsed time for different treatment

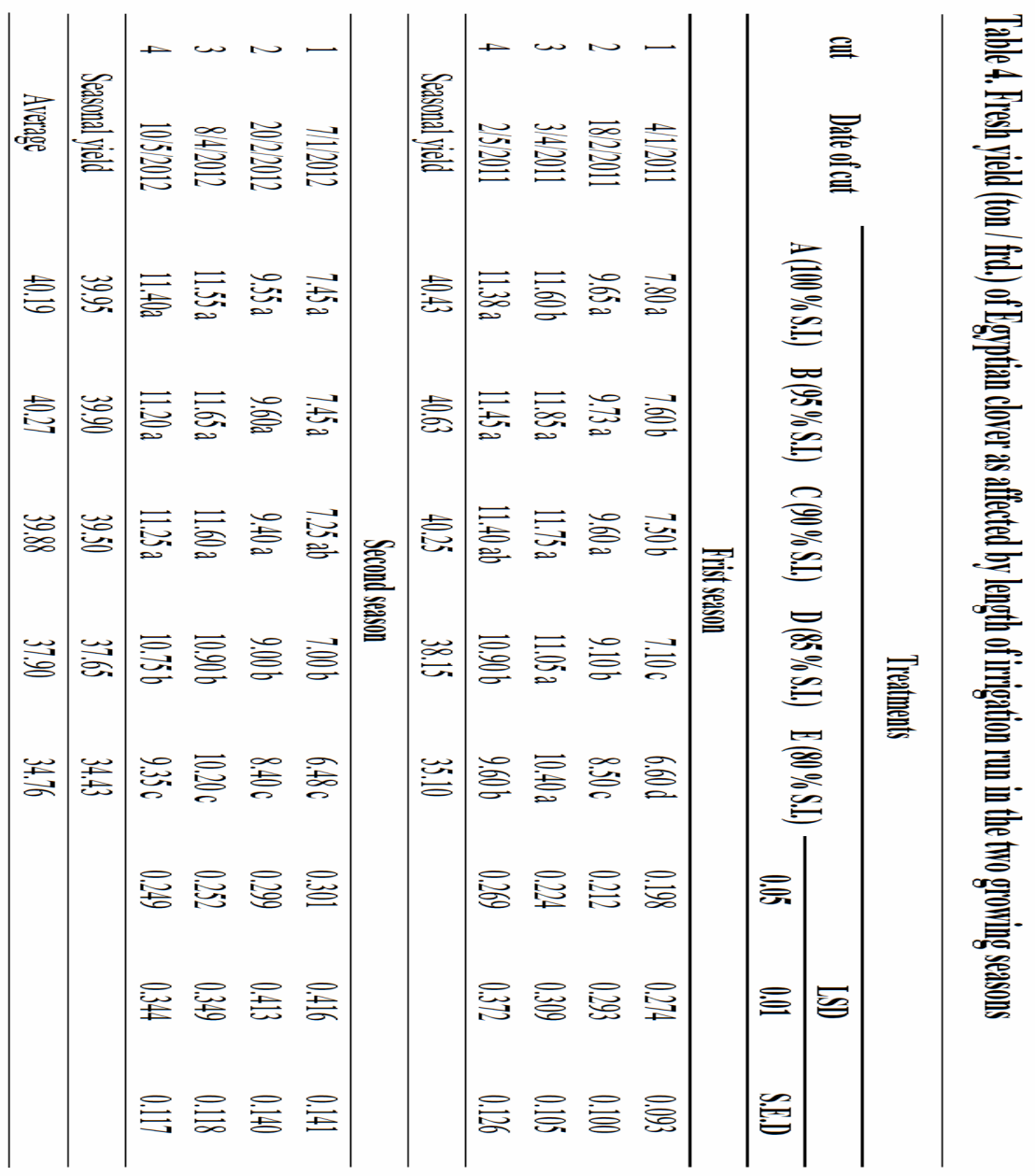




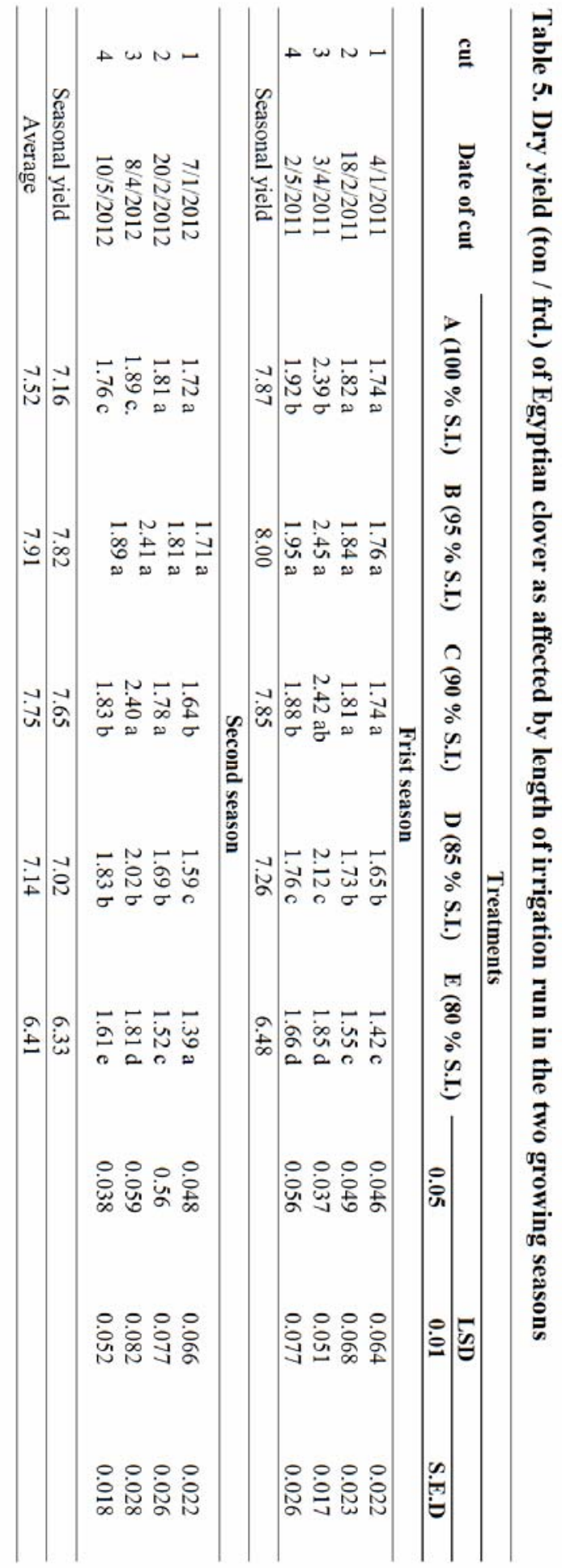




\section{CONCLUSION}

It might be concluded that irrigation berseem crop in North Nile Delta till $90 \%$ of strip length (Trt. C) have the same yield obtained that of Trt. A (irrigating till the strip end and B (95\% S.L), saving $7.9 \%$ of irrigation water and highest values of crop-water functions e.g. W Ut E $\left(24.80 \mathrm{~kg} \mathrm{~m}^{3}\right)$ and W U E (16.58 $\left.\mathrm{kg} \mathrm{m}^{3}\right)$.

\section{REFERENCES}

Abbas, F.A.; A.A. Rayan; K.A. Mohamed and N.G. Ainer (1995). Evaluation of water management system for clover in Egypt. Proc. of the $2^{\text {nd }}$ Conf. of on-farm irrigation and agroclimatology, Giza, Egypt, Jan. 2-4, 1995, p. 265-276.

Abo-Warda, A.M.A. (2002). Evaluation of some wheat genotypes under different irrigation treatments and nitrogen levels in sandy soil. Minufiya J. Agric. Res. Vol. 27(2): 181-196.
Azevedo, C.A.V. De; R. V. Pordeus; J.L. Silveira; V.L.A.Lima-de and Dantas, $\mathrm{N}$ et0 (2003). Influence of the required water depth on the furrow irrigation performance. IRRIGA 2003, 8:1,15-62

Badawi, A. Y.(1970). Water requirements of clover and main crops in 2 and 3-year crop rotation after the completion the High Dam. M. S. thesis. Fac. Of Agric., Cairo Univ., Giza, Egypt,

Doornbos, J. and W.O. Pruit (1975). Crop water requirements. Irrigation and Drainage Paper, No. 24, FAO Rome.

Hansen, V.W.; Israelsen and Q.E. Stringharm (1979). Irrigation principles and practices, $4^{\text {th }}$ ed., John Willey and Sons, New York.

Kassab, M.M. and M.A.M. Ibrahim (2007) Cut off wheat irrigation as an effective way for water management. Alex Sci. Exch.,28. (4) pp 158-167

Mahrous, F.N.; A.Y. Badawi; M.N. Seif El-Yazal; H.W. Tawadros and A. Serry (1984). Effect of soil moisture stress on Egyptian clover. Agric. Res. Rev. 62(4A): 39-50.

Snedecor, W.G. and W.G. Cochran (1967). Statistical methods. $6^{\text {th }}$ ed. Iowa State Univ., USA 


\title{
प] المض الم
}

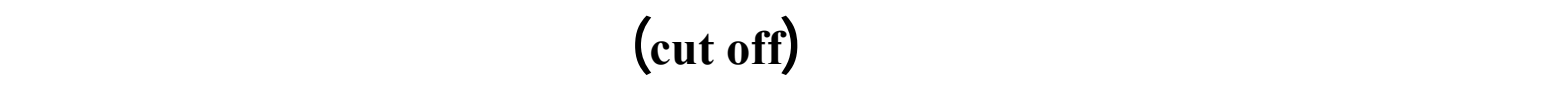

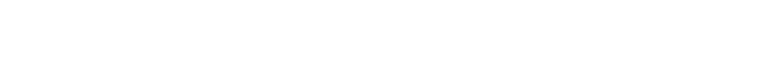

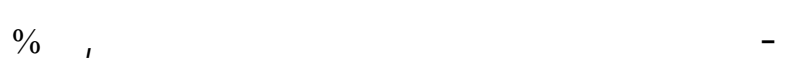
إ

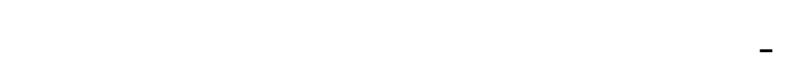

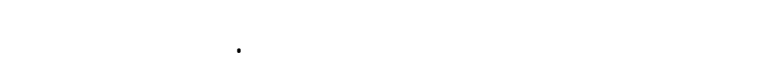
90 oه \% منطول الشرحه (معلdب).

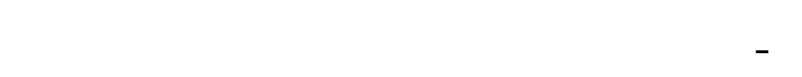

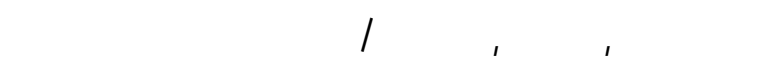

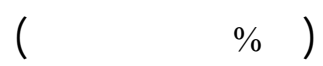

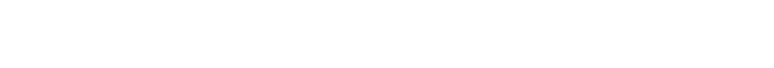

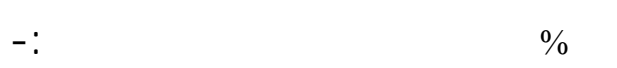

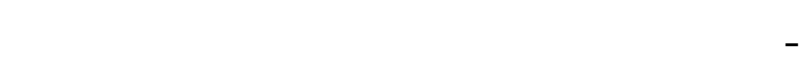

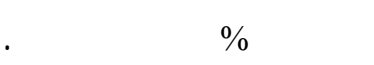

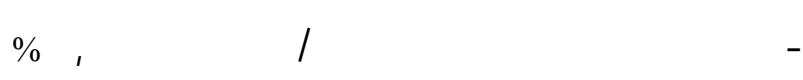

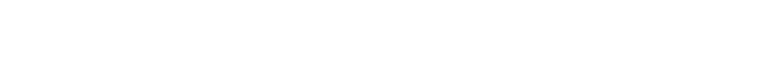
مليونم (r,0 مليون فدل).

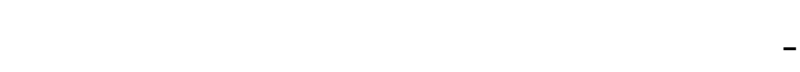

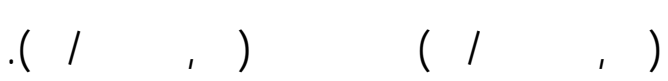

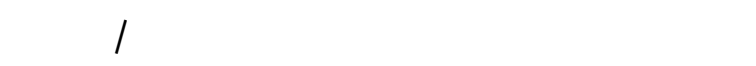

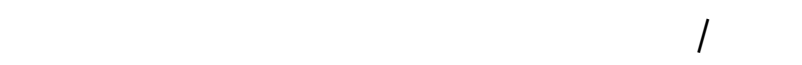
إيقل الري عندها وكذلك تظيم الوحة من [اء الهضلف وإنتاج

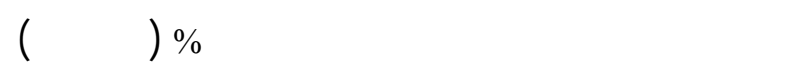

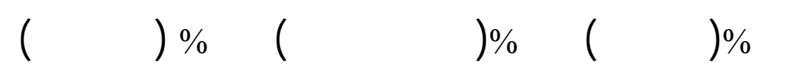

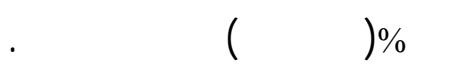

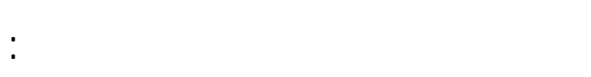

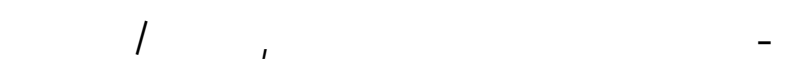

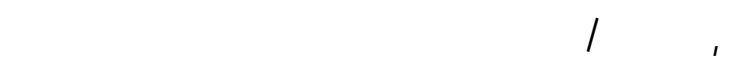
تنازيا: · الرئ, التزتيب.

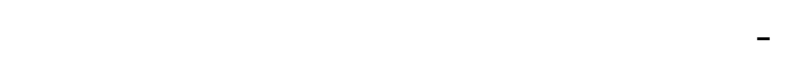

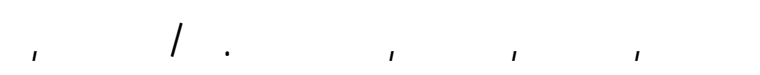

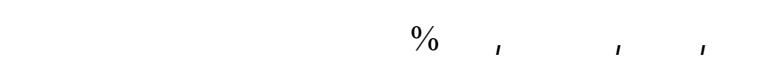
على الزتيب.

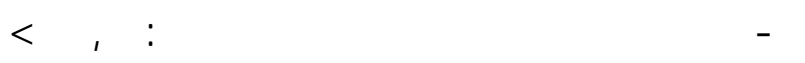

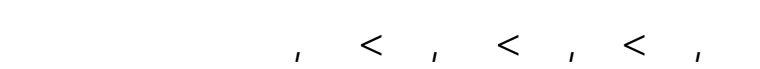

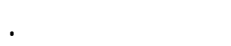

